$O$ anti-semitismo instala-se abertamente na Alemanha através de porta-vozes como Stocker, Marr e outros, fortalecido pelas teorias racistas que encontram finalmente o seu lugar e começam lentamente a ganhar a Alemanha desde 1900 .

Num terceiro capitulo (A noite nazista), Sorlin mostra objetivamente o caminhar do ódio no espírito alemão, - do pogrom à "solução final".

Com admirável espírito de síntese, ao traçar o quadro do judaísmo alemão; desde as suas origens, esclarcce episódios, e destaca etapas importantes, chegando ao anti-semitismo que permitiu aos nazistas as diabólicas elocubrações que todos conhecemos.

Dez documentos, transcritos em ordem cronológica, desde um édito de Frederico I em 1157 até um relato sôbre o vandalismo nazista em uma cidade renana em 1938 ( $L a$ nuit de cristal), enr:quecem o trabalho, que é completado ainda com tcxtos que levantam problemas e sugerem interpretaçōes, fornecendo um real e efetivo aproveitamento ao leitor.

SUELY ROBLES REIS DE QUEIROZ

ROULEAU (Bernard). - Le tracé des rues de Paris: formation, typologie, fonctions. Paris. 1967. "Centre National de la Recherche Scientique". Coleção "Mémoires et Documents". 130 páginas.

Inúmeros são os pontos de contacto entro a Geografia e a História. Se ao historiador compete analisar e compreender o desenrolar dos acontecimentos humanos, ao gcógrafo compete estudar e compreender a paisagem expressa na superfície terrestre. E' sôbre esta paisagem que se desenrolam os fatos pesquisados pelo historiador, mas também as ações humanas repercutem na formação e organização dos espaços, cuja dinâmica evolutiva torna-se objeto de pesquisa do geógrafo. Levando em consideração a interação dos fatos, cabe ao geógrafo possuir bom conhecimento histórico, assim como ao historiador é válido conhecer muito da geografia. E' ocorrência comum acontecer ao historiador fazer obra de interêsse geográfico, ou vice-versa, pois muitos assuntos e questões são melhor focalizados ou ganham nova compreensão quando abordados sob variadas perspectivas metodológicas.

A obra que vem de ser publicada na coletânea Memóires et Documents, do Centre National de la Recherche Scientifique, interessa a muitos estudiosos. A metodologia empregada é a geográfica, mas muito do métier do historiador está prisente em suas páginas. Estudando o trą̧ado das ruas de Paris: formação, tipologia e funções, o autor faz obra de geografia urbana. Mas a tarefa para ser completa teve que distinguir as marcas paisagísticas e a importância das várias fases históricas; para ser completa teve que analisar e compreender as várias concepções e critérios que nortearam as gerações que se preocuparam em criar, remanejar e adaptar as estruturas urbanas às contingências de cada época. Porque, com certo determinismo, o autor nos lembra que a "história das cidades não escapa à lei dos perpétuos recomeçar no mecanismo de sua expansão, desde que o retôrno de conjunturas semelhantes chama, necessàriamente, soluções idênticas". 
A sua preocupação metodológica pode ser resumida no seguinte trocho: "alguns documentos e obras, dos mais importantes para a história de Paris, não apresentam para nós senão um interêsse mínimo. Longe de quirer efetuar um histórico das vias de Paris, sòmente retivemos os dados que se relacionam com a origem da formação de uma via de passagem, às etapas de sua urbanização, para explicar ou servir de material à explicação de sua estrutura atual. Isto, no final das contas, permaneceu como nossa meta essencial. Da mesma maneira, climinamos tudo o que se relaciona com a formação de vias atualmente desaparecidas, a não ser que vcnham explicar a formação das vias atuais".

$\mathrm{Na}$ primeira parte encontramos os fundamentos da rêde topográf:ca de Paris. Inicialmente vemos a evolução desde as origens até o final do século XII, distinguindo os caminhos naturais da época gaulesa, os traçados romanos e as vias formadas na alta Idade Média; posturiormente o autor expõe o desenvolvimento da rêde das vias no século XIII,mostrando o traçado e as funções atuais dos caminhos ligados ao circu.to de Filipe-Augusto, e as repercussões oriundas com a instabilidade política e o "renascimento" de Paris no decorrer dos séculos XIV ao XVI; aborda dipois os acontecimentos relacionados com a obra jurídica e a utilização dos bens nacionais, ocorridos de 1790 a 1830 e, por último, as características da formação das ruas e de suas funções.

$\mathrm{Na}$ leitura desta obra de Rouleau realça a acuidade de uma pesquisa minuciosa, que se reflıte numa descrição detalhada e muito bem documentada. As ilustrações somam quinze cartas e vinte e três figuras, facilitando o acompanhamento do texto e das transformações havidas, além de uma carta de referência na escala de 1:25.000, expondo as vias parisienses principais e seus nomes. A propósito desta carta de referência,assim como em outras encontradas no texto, cumpre lembrar uma questão de terminologia. : A carta inserida denomina-se "plano topográfico de Paris", apresintando a distribuição das ruas parisienses. Ora, o têrmo topográfico, nos estudos geográficos, aplica-se normalmente às cartas representativas das formas de rílêvo de uma área, e não ao traçado urbano. Mas, como um grão de areia não caractcriza a praia, e a omissão acima pode ser colocada nesta proporção, a obra de Rouleau é fundamental para quem se interessa em realmente conhecer a geografia e a evolução histórica da capital francesa.

\section{ANTONIO CHRISTOFOLETTI}

GOODSPEED (D. J.). - Ludendorff. Rio de Janeiro. 1968. Tradução de Eloywaldo Chagas de Oliveira. Biblioteca do Exército em co-edição com a Editôra Saga. 345 páginas.

Justificando a publicação desta obra e eximindo-se de qualquer crítica que porventura the possa ser feita, apressa-se a editôra em explicar que ao lançar a biografia de Ludendorff, "Ionge de nós a idéia de reviver o prussianismo ou de pugnar pela apologia da guerra, pois como militares que somos, conhecemos melhor que ninguém quais os horrores que dela decorrem. No desijo de fornecer aos 